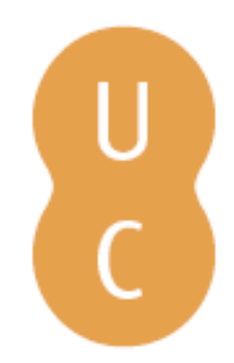

\title{
nommalina
}

\section{and its derivatives in the Plutarchan works on love}

Autor(es): Jesus, Carlos A. Martins de

Publicado por: Imprensa da Universidade de Coimbra

URL

persistente: URI:http://hdl.handle.net/10316.2/32875

DOI: $\quad$ DOI:http://dx.doi.org/10.14195/978-989-721-012-9_6

Accessed : $\quad$ 26-Apr-2023 15:19:24

A navegação consulta e descarregamento dos títulos inseridos nas Bibliotecas Digitais UC Digitalis, UC Pombalina e UC Impactum, pressupõem a aceitação plena e sem reservas dos Termos e Condições de Uso destas Bibliotecas Digitais, disponíveis em https://digitalis.uc.pt/pt-pt/termos.

Conforme exposto nos referidos Termos e Condições de Uso, o descarregamento de títulos de acesso restrito requer uma licença válida de autorização devendo o utilizador aceder ao(s) documento(s) a partir de um endereço de IP da instituição detentora da supramencionada licença.

Ao utilizador é apenas permitido o descarregamento para uso pessoal, pelo que o emprego do(s) título(s) descarregado(s) para outro fim, designadamente comercial, carece de autorização do respetivo autor ou editor da obra.

Na medida em que todas as obras da UC Digitalis se encontram protegidas pelo Código do Direito de Autor e Direitos Conexos e demais legislação aplicável, toda a cópia, parcial ou total, deste documento, nos casos em que é legalmente admitida, deverá conter ou fazer-se acompanhar por este aviso. 


\section{Nomos, Kosmos \& Dike in Plutarch}

José Ribeiro Ferreira, Delfim F. Leão \& Carlos A. Martins de Jesus (eds.) 


\title{
kozmos and its derivatives in the Plutarchan Works on love
}

\author{
Carlos A. Martins de Jesus \\ Universidade de Coimbra
}

\begin{abstract}
This paper aims to explore the different meanings of the word kó $\mu \circ \varsigma$ and its derivatives, also looking for a unified understanding of them in the Plutarchan works on love, namely Amatorius, Amatoriae Narrationes, Coniugalia Praecepta, Mulierum Virtutes and Consolatio ad Vxorem. By analyzing first a more general and primordial meaning of 'cosmical organization' and then a more domestic one - that of female cosmetics -, as well as others, an attempt is made to understand Plutarch's use of those words, as well as the moral and philosophical principles they imply.
\end{abstract}

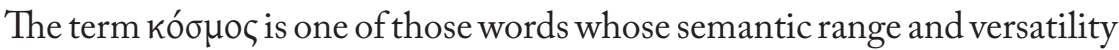
most surprises philologists, since even words which are etymologically derived from it can be seen to bear the imprint of its diversity. When Plutarch, in the second century $\mathrm{AD}$, uses it to characterize the position of women in the context of a loving relationship, especially marriage - and I refer mainly to the works Conjugalia Praecepta, Consolatio ad Vxorem and Amatorius -, there is already an immeasurable philosophical and linguistic tradition conveyed by

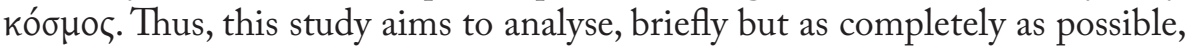
the appropriation and manipulation of this term by Plutarch.

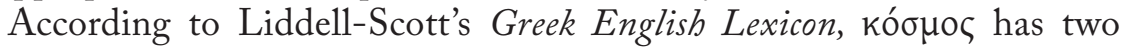
primary meanings: (1) "order", that corresponds to the semantic value of $\tau \alpha \xi_{1 \zeta}$ (cf. Latin ordo) ${ }^{1}$, and, also related to the previous one, (2) "ornament" or "adornment" (cf. Latin ornamentum, ornatus). In fact, they both came to signify the same idea of aesthetical organization of unrelated elements and it is actually difficult to detect which one comes first in Greek language and literature. In relation to its more concrete and scientific sense still used nowadays - "cosmos" or "cosmic order" - it is traditionally ascribed first to Pythagoras (apud Placit. 2.1.1, D.L. 8.48; cf. [Philol.] 21) and Parmenides (Thphr. ap. D.L. 1.c.), although it is already found in the fragments of their predecessors, such as Anaximander (fr. 12A 10 Diels) and Anaxymenes (fr. 13B 2 Diels). Nevertheless, it must have reached this meaning, in a definitive way, by the time of Empedocles (fr. 134 Diels)². However, Greek literature

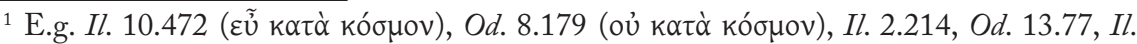
12.225; Hdt. 2.52, cf. 7.36; Ar. Av.1331; Pi. P. 3.82; A. Ag. 521; Hdt. 8.86, 9.59, 9.66; Th. 3.108; A. Pers. 400. It also started to relate to the specific order of States (e.g. Th. 4.76, cf. 8.48, 67; Hdt. 1.65).

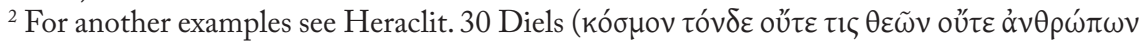


shows that it soon gained moral connotations related to attitudes and conducts in several areas, the ones listed in the Thesaurus Linguae Graecae under the category of "modo et ratione omnia facere" and "decens habitus"3.

In fact it is within this last sense that we must place the Plutarchan use of the term and its derivatives, especially when referring to female conduct in the context of a loving relationship, preferably marriage. Lamprias'

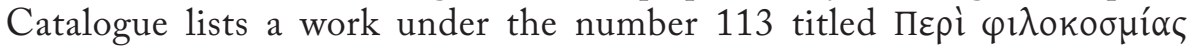
("On the love for adornments"), which, despite the lack of testimonies or fragments 4 , we can reasonably conceive that it might also advocate the value of other type of adornments, those that enrich a woman's soul and make her an example to other women. Regarding female conduct, the entry of the Thesaurus is clear when considering "quod ad ornatum muliebrem transtulit Plutarchus (Mor. 141E)". It refers to one passage of the Conjugalia Praecepta (141E), which is very elucidative of Plutarch's linguistic use of this term, going as follows:

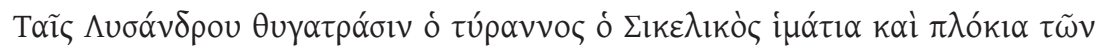

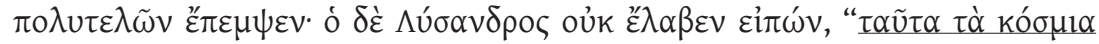

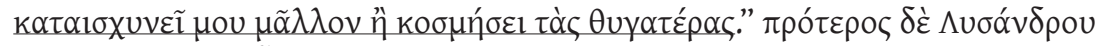

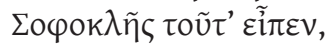

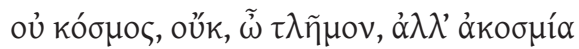

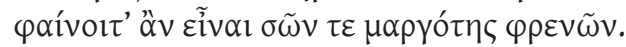

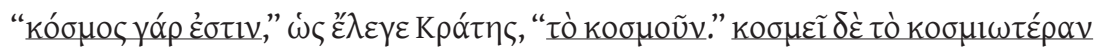

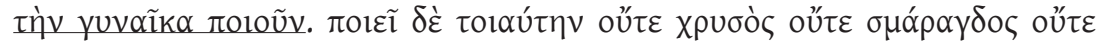

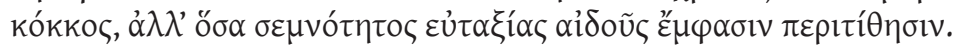

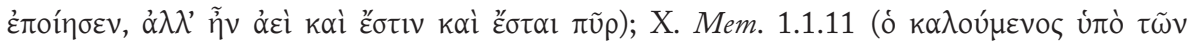

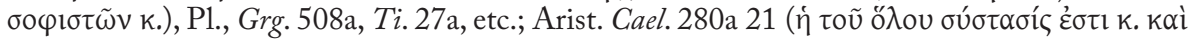
oủpavó(); Epicur. Ep. 2 p.37 U, Chrysipp. Stoic. 2.168, etc. For other derivated meanings see Posidon. ap. D.L. 7.139, Isoc. 4.179, Arist. Mete. 339a 20, Herm. ap. Stob. 1.49.44, [P1.], Epin. 987b, Anaximand. et alii ap. Placit. 2.1.3, etc.

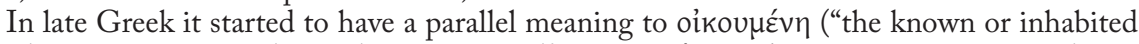

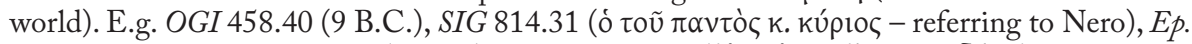

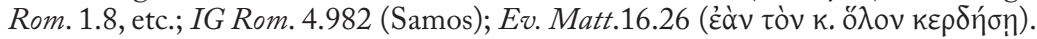

${ }^{3}$ E.g. Il. 2.214, 5.759, 8.12, 8.179; Od. 3.138. See also Hdt. 8.60, 142; Ar. Nu. 914; Th. 1.5; D. 60.36; X. Cyr. 6.4.3; Arist. EN 1124a 1. Therefore, it opposes to ókoouía, as expressed in the fragment of Sophocles (Soph. fr. 762, cit. Plu. Conj. praec. 141E). In fact, in a popular passage

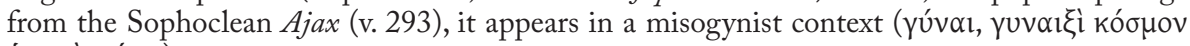

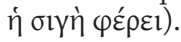

${ }^{4}$ In the Conjugalia Praecepta (145A) Plutarch alludes to a similar themed work (with no mention to the title) that had supposedly been written by his wife, Timoxena. U. Wilamowitz-Moellendorf F 1962: 655 suggested that this authorship was fictional and that it was, in fact, written by Plutarch himself. 
The Sicilian despot sent clothing and jewellery of the costly kind to the daughters of Lysander; but Lysander would not accept them, saying, "These adornments will disgrace my daughters far more than they will adorn them." But Sophocles, before Lysander, had said this:

Adornment! No, you wretch! Naught that adorns

'Twould seem to be - your crazy mind's desire.

For, as Crates used to say, "adornment is that which adorns", and that adorns or decorates a woman which makes her more decorous. It is not Gold or precious stones or scarlet that makes her such, but whatever invests her with that something which betokens dignity, good behaviour, and modesty ${ }^{5}$.

By telling this tale ${ }^{6}$ about the gifts that might have been received by the daughters of Lisander, the Spartan general of the V-IV centuries BC to whom he dedicated an entire biography, Plutarch plays with the double meaning of

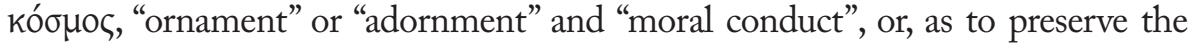
ambiguity of the Greek expression, "moral ornament". This can be inferred from the statement that such adornments ( $\tau \dot{\alpha}$ kó $\sigma \mu l \alpha$, stricto sensu), more than "adorning"

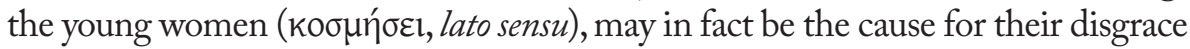

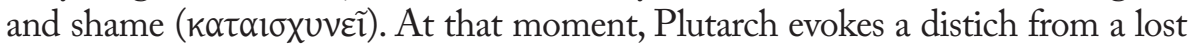
Sophoclean play (fr. $762 \mathrm{Nauck}^{2}$ ), in which the same opposition is expressed by the

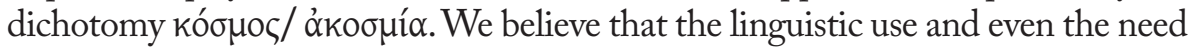
of summoning not one but two ancient definitions reveal the acknowledgement that a delicate matter is being discussed, mostly due to the semantic ambiguity of the term in use. The ambiguity is not even solved by Crates' very simple

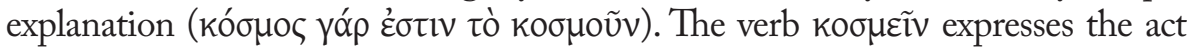

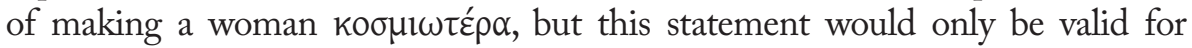
physical adornments. Thus it becomes necessary to clarify that the "cosmetics" being discussed - the one that Plutarch prescribes to Eurydice, the bride to whom the speech is addressed - is not made of gold, gems or lavish fabrics but, instead,

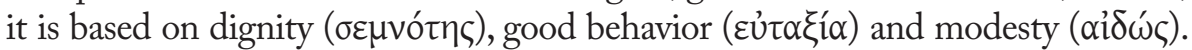
Those are the adornments that make a woman innerly "organized" and "balanced", those are the accessories of her moral cosmetics.

The same characterization of the ideal woman in the context of marriage comes later in the same work, when the final advice to the grooms is being given $(145 \mathrm{E}-\mathrm{F})$ :

\footnotetext{
${ }^{5}$ All English translations, unless otherwise is mentioned, are from the Loeb Classical Library.

${ }^{6}$ It was probably a legendary story, suitable to different characters. Therefore Plutarch applied it also to Archidamus (Apopht. Lac. 218E).
} 


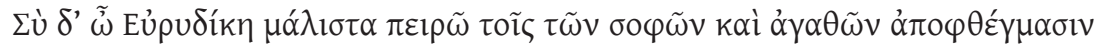

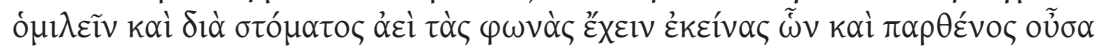

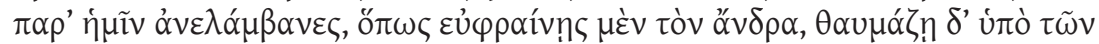

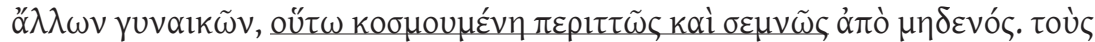

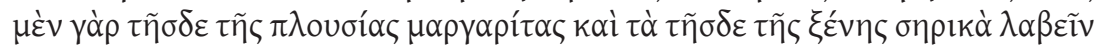

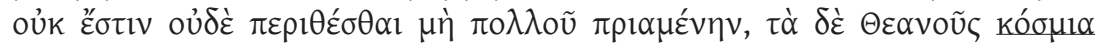

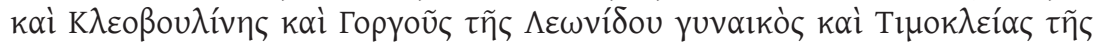

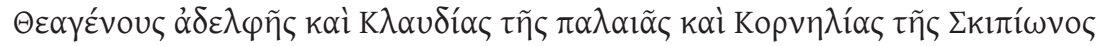

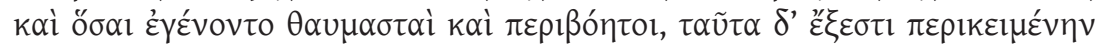

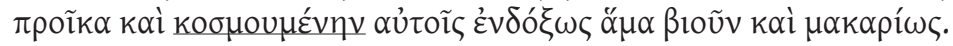

As for you, Eurydice, I beg that you will try to be conversant with the sayings of the wise and good, and always have at your tongue's end those sentiments which you used to cull in your girlhood's days when you were with us, so that you may give joy to your husband, and may be admired by other women, adorne, as you will be, without price, with rare and precious jewels. For you cannot acquire and put upon you this rich woman's pearls or that foreign woman's silks without buying them at a hight price, but the ornaments of Theano, Cleobulina, Gorgo, the wife of Leonidas, Timocleia, the sister of Theagenes, Claudia of old, Cornelia, daughter of Scipio, and of all other women who have been admired and renowned, you may wear about you without price, and, adorning yourself with these, you may live a life of distinction and happiness.

Once again use is made of the image of female cosmetics' precious adornments, pearls of moral conduct that, being materially more accessible, enable a woman to give joy to her husband and commend herself to the admiration of other women. The use of specific examples, common in the Plutarchan works - in this case simple allusions that appear in accumulation - aims at making a series of conduct paradigms linger in the bride's mind, stories that shift from truth and legend, which, in fact, fulfill a valuable paradigm ${ }^{7}$. Common in epideictic rhetoric ${ }^{8}$, two key levels that contribute to

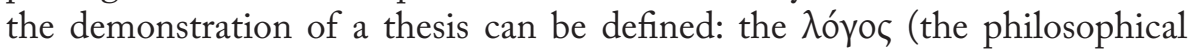

7 The models presented by Plutarch are the following: Theano, Pythagoras' wife, referred once again later (142C); Cleobuline, daughter of Cleobulus - one of the Seven Sages -, supposedly the author of some enigmas in hexameter whom, in the Banquet of the Seven Sages, Thales calls a philosopher; Gorgo, daughter of Cleonomes, king of Sparta, and wife of Leonidas. About Gorgo it is told in the Mulierum Virtutes (225A, 227E-F) that, being asked why only Spartan women were said to have power over their husbands, she replied that only they were mothers of true men; Timocleia, whose story of courage and virtue is also told in the Mulierum Virtutes (259D-260D); Claudia, a Roman vestal that, after being accused of having been defiled, dragged alone a boat that was carrying a statue of Cybele to the city; Cornelia, mother of the Gracchi and Scipio the Africanus, that once referred to her sons as "jewels".

${ }^{8}$ Several Greek authors theorize about how indispensable exempla are to achieve persuasive purposes: e.g. P1. Plt. 277d 1-2, Arist. Rh. 1357b 27-30. 
discussion itself), which is continuously helped by a series of $\mu \tilde{v} \theta$ or or $\pi \alpha \rho \alpha \delta \varepsilon i ́ \gamma \mu \alpha \tau \alpha$ with distinct levels of narrative development. As has been well perceived by J. A. Clúa Serena 19979, we are in the presence of a clear purpose of the $\lambda$ óyoc: to present, by resorting to $\mu \tilde{v} \theta$ oc, the most suitable themes in the range of the eikós (the plausible) ${ }^{10}$.

The conduct implied in the female kó $\mu \iota \propto \alpha$ prescribed by Plutarch is built on the concepts of order, modesty and silence, as can be seen in two passages of another brief Plutarchan work, the so-called Consolatio ad Vxorem. It presents itself in the narrative structure of a letter that Plutarch himself may have written to his wife, Timoxena, on the death of their only daughter, named after her mother, the last of their five children (608C). This work does not actually prescribe the proper conduct of a future wife, as Timoxena is repeatedly presented as being already the complete prototype of a perfect wife; however, Plutarch praises the decorum and silence of her attitude towards the death of her daughter, stating that "everything was

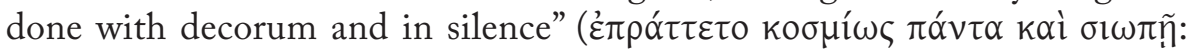
$608 \mathrm{~F}$ ) and emphasizing "the self-possession with which [she] kept order in [her] house-hold at the time that gave full scope to disorderly confusion"

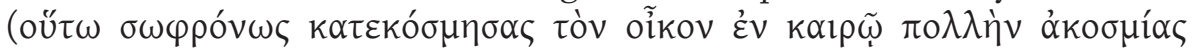

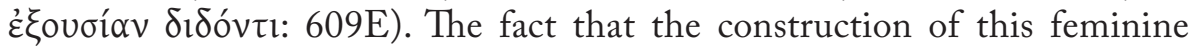
profile depends, in a large scale, on the husband's character is supported by Plutarch in another passage of the Conjugalia Praecepta (140C), based on an interesting linguistic game:

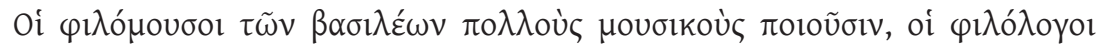

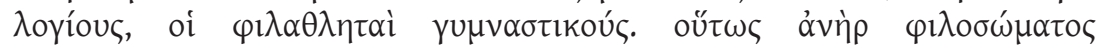

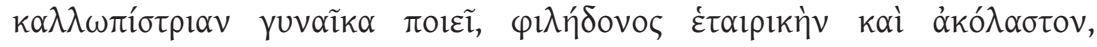

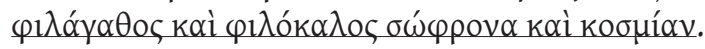

Kings fond of the arts make many persons incline to be artists, those fond of letters make many want to be scholars, and those fond of sport make many take up athletics. In like manner a man fond of his personal appearance makes a wife all paint and powder; one fond of pleasure makes her meretricious and licentious, while a husband who loves what is good and honourable makes a wife discreet and well-behaved.

\footnotetext{
${ }^{9}$ The author studies the narratives (realia) presented in another work, the De sera numinis vindicta, a compilation of the life stories of a few tyrants in the hands of the Providence.

${ }^{10}$ In relation to the structure and function of this type of shorter exempla, true autonomous narratives with a similar paradigmatic function, see F. Frazier 2005 and M. Valverde SÁNCHEZ 2007.
} 
R. M. Aguilar 1990: 316 correctly assumes that statements such as this one, more than misogynistic, are in fact the result of the social evolution of women's status in the Hellenistic and Roman world, as silence and modesty are only prescribed to the moments when a woman is alone, without her husband ${ }^{11}$.

It is however in the Amatorius - perhaps the most popular, disseminated and imitated of all the Moralia - that Plutarch made the highest investment in terms of philosophical and moral precepts about love and female conduct in marriage, since that is the main subject of the dialogue. The "dramatic" situation is clear: Plutarch and his wife had gone to Helicon to make sacrifices to Eros, at the time when an astonishing local event dominated the conversations: Ismenodora, a mature widow, desired to marry Bacon, a young and single man. Then, two inhabitants, Anthemion and Pisias, approach Plutarch with opposing opinions on the matter, clearly advocating each side of the discussion - paederastic versus conjugal love. Hence it aims to philosophically legitimize heterosexual love and to acknowledge the decisive role of women in the pursuit of true love, as she may also be able to foster and inspire the effects triggered by true Eros. Plutarch puts the reader before an extreme situation as Ismenodora, more than a random woman, is a mature widow, being beforehand more experienced than Bacon, the young man that she desires. Therefore, the manipulation of traditional philosophical arguments on love, mostly Platonic ${ }^{12}$, is clear throughout the whole dialogue.

Indeed, regarding philosophical theories on love, the Banquet and the Phaedrus are the most direct models of the Amatorius, alongside noticeable influences of passages from the Phaidon, the Republic or the Laws. By recalling Plato's notion that Eros is the guide of souls to supreme Beauty, the Polygraph shows the evolution of coeval thinking and strips the original misogyny of the Platonic theory, by giving woman a determinant role and - as well stated by $\mathrm{M}$. B. CRAwFord 1999: 290 - by rescuing marriage from a linear and anti erotic conception $^{13}$. At other moments, several philosophical doctrines merge to address the same subject, but Plato is indeed to be seen as the main inspiration.

${ }^{11}$ This becomes clearer in another passage from the Conjugalia Praecepta (139C), by resorting

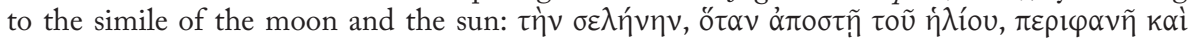

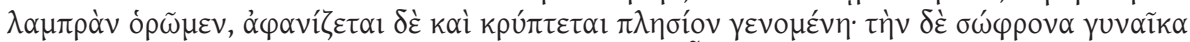

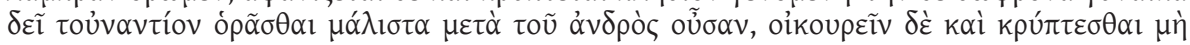

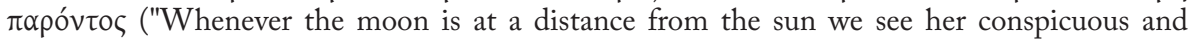
brilliant, but she disappears and hides herself when she comes near him. Contrariwise a virtuous woman ought to be most visible in her husband's company, and to stay in the house and hide herself when he is away").

${ }^{12}$ From the many titles focused on the Platonism in Plutarch, especially in relation to the love theme, see H. Martin 1984, F. Frazier 1999, 2008a, A. Billaut 1999, J. Boulogne 1999, M. B. Crawford 1999, J. M. Rist 2002 and P. Gilabert Barberà 2007.

${ }^{13}$ See also F. E. Brenk 1988, who reaches a similar conclusion. 
Plato had also used the term kó $\sigma \mu$ ○ and its derivatives in the philosophical legitimization of paederastic love in order to refer himself to the conduct of the ideal lover, as a vehicle to achieve Beauty and Good, the aim of the true Eros. An unequivocal example appears in the Symposium (187d-e), after the distinction between two Eros and two Aphrodites (180d-182a), a subject recapped by Plutarch in his dialogue (764B-765D). The Platonic text goes as follows:

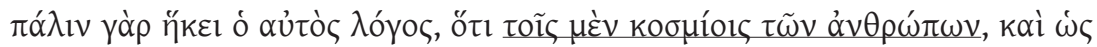

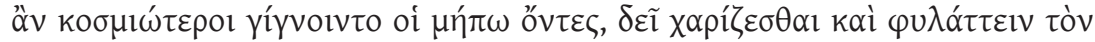

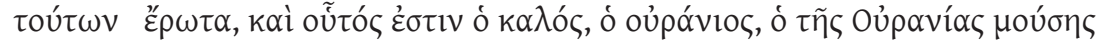
"Е $\rho \omega \varsigma^{\circ}$

Round comes the same conclusion: well-ordered men, and the less regular only so as to bring them to better order, should be indulged in this Love, and this is the sort we should preserve; this is the noble, the Heavenly Love, sprung from the Heavenly Muse.

To another level, in Plato's Symposium references to the value of

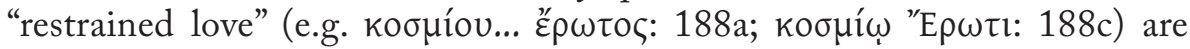
frequent, and one may come to accept that Plutarch might have used the same linguistic expression in his works on that subject. Nevertheless, the kó $\mu_{1} \alpha$ that Plato uses as an ethical, moral and even political value in the masculine ${ }^{14}$ will appear in Plutarch with new drapery and, deliberately, in the feminine. Thus, it is our belief that the rhetoric interrogation to which

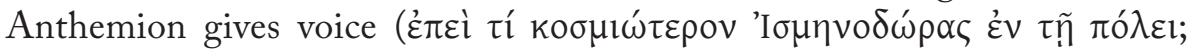
Amat. 755D) is intentional, since the whole discussion of the dialogue aims to attempt a proper answer to it.

In order to inspire true love, Ismenodora's conduct should not reduce itself to the kó $\tilde{\mu l \alpha}$ of a woman who stays at home with all her decency and modesty,

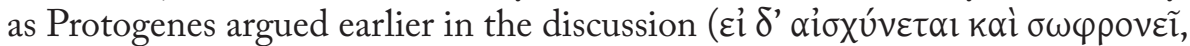

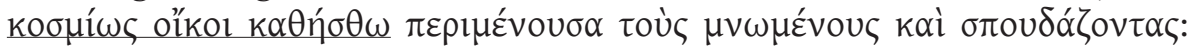
$753 \mathrm{D})$. The Platonic discussion on love $(766 \mathrm{E}-768 \mathrm{~F})$ is carried on against this unambiguous misogyny, aiming to demonstrate, by recurring to the same arguments used by Plato, that true Eros does not obey gender issues. It only

${ }^{14}$ There are several Platonic passages in which the ethical sense of this term and its derivatives

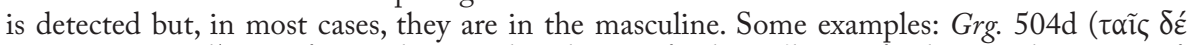

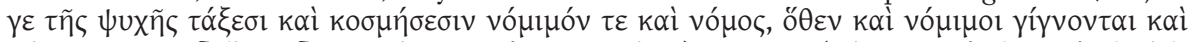

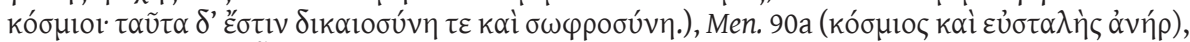

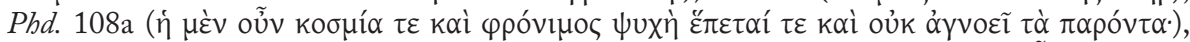

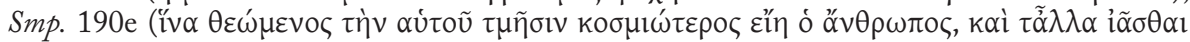

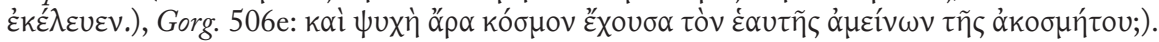


leads a person to make his/her choice by the beauty and virtue of other being (767A):

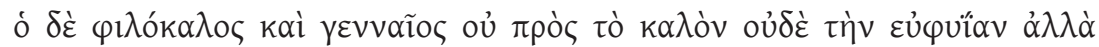

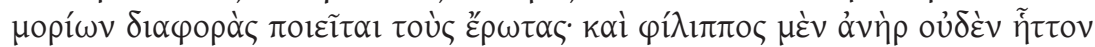

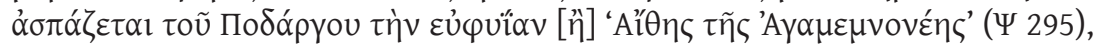

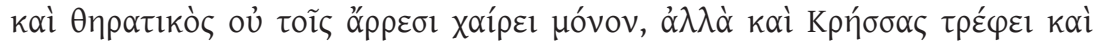

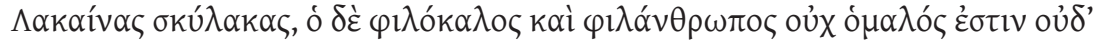

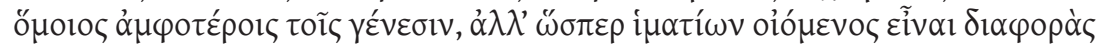

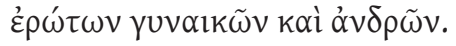

... the noble lover of beauty engages in love wherever he sees excellence and splendid natural endowment without regard for any difference in physiological detail. A lover of horses takes pleasure in the excellent qualities of Aethê, Agamemnon's mare no less than in those of the horse Podargus. The hunter has no special preference for male dogs, but also keeps Cretan and Laconian bitches. So to will not the lover of human beauty be fairly and equably disposed toward both sexes, instead of supposing that males and females are as different in the matter of love as they are in their clothes?

Therefore, the Platonic inspired argumentation in Plutarch is to be understood as the amplification of Plato's own arguments on love for both genders, instead of being a gender shift. It intends to legitimize conjugal love, first philosophically, then ethically. The afore mentioned amplification is based on the defense of the ideal $\ddot{\eta} \theta$ os of true love, notwithstanding its gender:

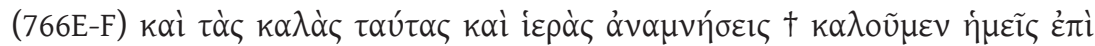

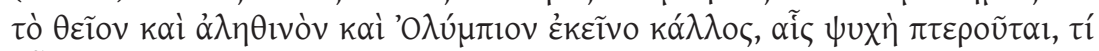

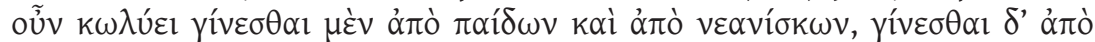

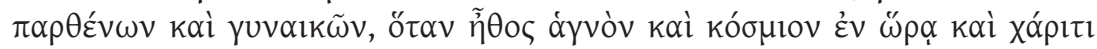

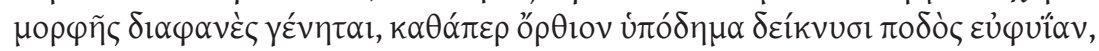

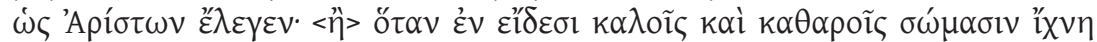

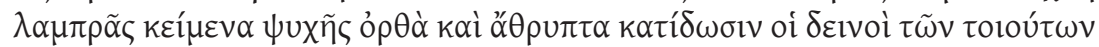

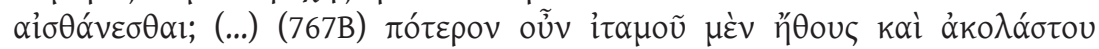

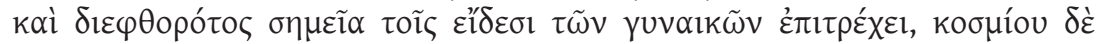

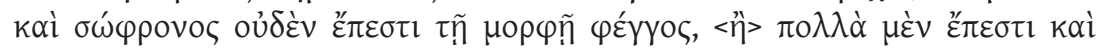

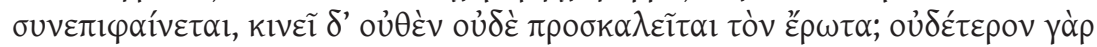

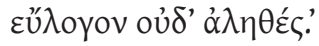

(766E-F) And those beautiful and sacred passions which we call recollections of the divine, the true, the Olympian beauty of the other world, by which the soul is made winged -why should they not spring from maidens and women, as well as from boys and striplings, whenever a pure and disciplined character shines through from within a beautiful and charming outward shape... or 
whenever the clear-cut traces of a shining soul stored up in beautiful forms and pure bodies are perceived undistorted, without a flaw, by those capable of such perceptions. (...) (767B) Do the 'signs' betokening a flight, unchaste, and corrupt character overrun women's faces, while no luster is added to a female's beauty by a chaste and modest character? Or are there many 'signs' of the latter, which 'present themselves in combination', yet nevertheless do not move or evoke our love? Neither position is well taken or true.

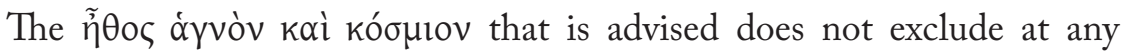
moment the role of physical pleasure and $\operatorname{sex}^{15}$, as they should always be moderated and calculated ${ }^{16}$; instead, it tries to elevate pleasure to a superior stage, to the Platonic supreme Good. At that stage, there is no great difference to the paederastic love advocated by Plato, in which modesty and decency of the young male lover was also recommended. The implied decorum in the кó $\sigma \mu l \alpha$ of the lover is more related to a conduct that inspires total fidelity and concentration on one being, as it can be concluded in the following passage (767E-F):

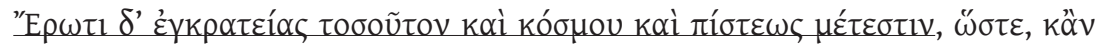

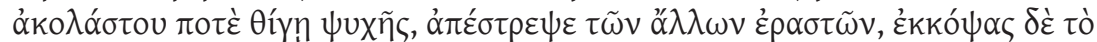

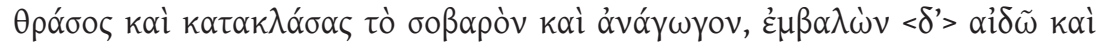

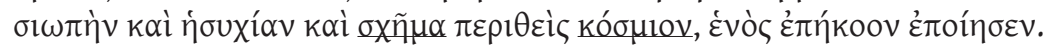

Love, however, has in himself enough self-control, decorum and mutual trust, so that if he ever but touches the heart even of a profligate, he turns him from his other lovers, drives out insolence, humbles pride and intractability, and brings in modesty, silence, calm. He clothes him with the robes of decorum and makes him deaf to all appeals but one.

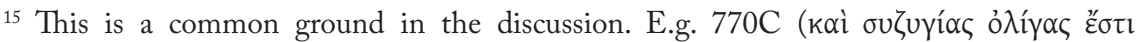

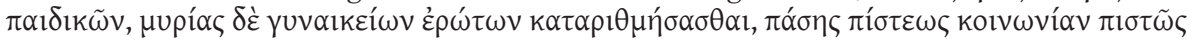

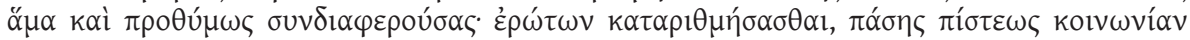

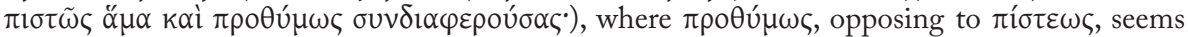
to allude to the physical part of a conjugal relationship. Therefore, it reminds and compliments the Solonian law according to which spouses should have sexual intercourse at least three times a month, as Plutarch says, "definitely not by the pleasure itself but - in the same way that cities, from time to time, renew the pacts that they have among each other - because they wanted to revitalize the marriage from the complaints that accumulates day by day with such a display of

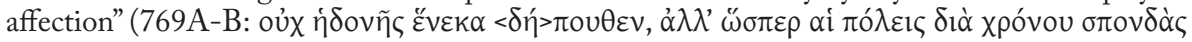

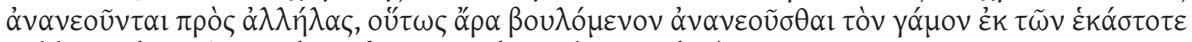

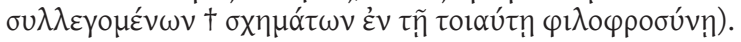

${ }_{16}$ J. F. Martos Montiel 1990, 1999a, 1999b: 111-125 developed the notion of calculation of pleasure by the conception of a $\mu \varepsilon \tau \rho \tau_{0} \alpha \varepsilon \varepsilon 1 \alpha$ that gathers Platonic, Aristotelian and Epicurean influences, and departs from the stoic ó $\pi_{\alpha} \alpha \dot{\theta} \varepsilon 1 \alpha$. About the reception of Epicurism in Plutarch, mainly in the Amatorius, see A. BARIgazzi 1988. 


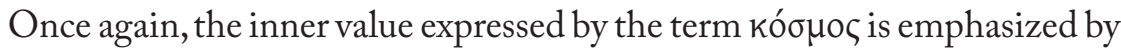
the image of exterior clothing, with garments of nobility and decorum existing

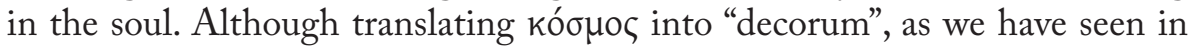
the just quoted passage, may seem too moralizing, several different translations that we found, once compared, prove that its main sense is that of "moral adornment or cosmetics". Moreover, it may be said that both Plutarch and his translators seem to agree on keeping this ambiguity within the cosmetics' semantic range, the exterior and interior ones.

Taking into account the above-explained argumentative logic, according to which a finished theory demands exemplary illustration, we are presented with the story of Lais (767F-768A). She was a famous courtesan from Corinth who might have been intimate with Aristippus of Cyrene, a philosopher of Socrates' circle, known for being the founder of the Cyrenaic school of Philosophy and one of the predecessors of Epicurism. The story concerns the love that she might have dedicated to the Thessalian Hipollocus, for whom she abandoned the profession of courtesan, her homeland and, finally, her own life, as other women's jealousy came to be responsible for her death. In fact, the conclusion of her story is categorically paralleled to the previous argument: "escaping secretly from the vast throngs of her other lovers and from the great

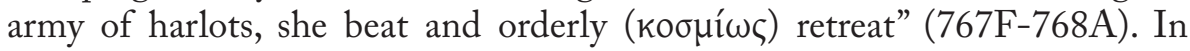
this specific passage, our opinion diverges from the translation of the Loeb

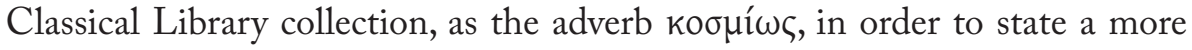
direct identification between the argument and the exemplary illustration, should have also a moral sense in the case of Lais, instead of the most concrete one that describes only her "orderly retreat". We would thus translate the adverb as "virtuously" or, as we actually did in our Portuguese translation of the Amatorius, "covered with honour".

An attentive reading of the works that we discussed seems to prove that Plutarch focuses on the characterization of the female kó $\sigma \mu l \alpha$ to reinstate women as a determinant element in love relationships, especially in a conjugal one. Implied or explicit characteristics as silence, decorum, modesty or fidelity

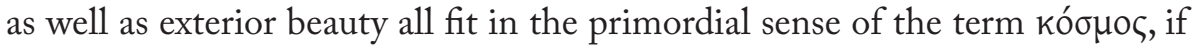
understood as "organization" or "balance" of pre-existing elements. Therefore, the woman who is kóoun, as intended by Plutarch, is the one that shows, both innerly and externally, the presence of adornments at the right amount and disposition, in the same way that the Pythagoreans stood for the barmonia as the principle of all cosmic (universal) organization. Taking the subject further, one may still read in Plutarch the influences of the Platonic theory on kó $\mu_{0}$, mainly the one from Timaios. If such a reading is possible, in the same way that

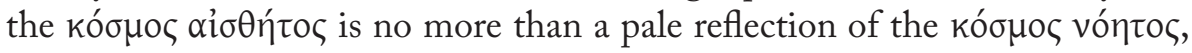
also a woman's external adornments would be nothing other than reflections, 
pale images of those other adornments with which she embellishes her soul. Hence, by comparison, Timoxena - the author's wife - is the ultimate model to work on the descriptions of other historical or legendary examples. The Galatian Camma ${ }^{17}$ (Amatorius 768B-D; Mulierum Virtutes 257E-258C) and Empone $^{18}$ (Amatorius 770D-771C) are perhaps the most polished examples.

However, the question cannot be read in every work that we have discussed in the same terms. F. Frazier 2008b: XX has hit the target when saying: "sans doute n'est-il pas difficile non plus de dégager une certaine 'rhétorique de l'exagération' dans la défense de l'amour conjugal de Plutarque, particulièrement sensible dans sa condamnation des viragos austères (753D), assez différente des propos plus mesurés qu'il tient sur le thème dans ses Préceptes conjugaux." As we have previously mentioned, it is clearly Plutarch's intention, with the Amatorius, to present his readers with a limit situation illustrated by limit examples ${ }^{19}$, and that is why, in this dialogue, Ismenodora is so different from Timoxena's model in the Praecepta. Nevertheless, both these women have an inner ability to inspire true love, the one that lives by the correct combination of pleasure and friendship; a combination already consummated in Timoxena, but also possible in Ismenodora. She may thus be seen, despite her singularities, as a more practical and realistic feminine prototype.

17 The character of Camma was studied by F. Frazier 2005 and F. E. Brenk 2005. She was an authentic romantic heroine. After her husband's death, when his assassin wanted to marry her, she pretended to be interested in him and then killed him, by poisoning, and ended up committing suicide. This story is not transmitted by any other source before Plutarch, being developed in the Amatorius and, and in a greater extent, in the Mulierum Virtutes. Nevertheless, this episode is addressed by Polienus (Strat. 8.39) in a very similar way to Plutarch, mostly to the version portrayed in the Mulierum Virtutes. Therefore, one may come to think that Polienus knew Plutarch's version, the one that influenced at least two tragedies in the Modern Period: Camma, reine de Galatie, of T. Corneille (1661), and The Cup, of Alfred Lord Tennyson (1884).

${ }^{18}$ Other sources are Tac. Hist. 4.67 and D.C. 65.3. We have studied this character ourselves, in a recent paper: C. A. M. Jesus 2011.

${ }^{19}$ The Amatorius is pertinently understood as an exercise of "rhetoric of exaggeration" by F. E. BRENK 2000: 45-60. 


\section{Quoted bibliography}

Aguilar, R. M., "La mujer, el amor y el matrimonio en la obra de Plutarco", Faventia 12-13, 1990: 307-325.

Barigazzi, A., "L'amore: Plutarco contro epicuro", Quad. Giorn. Fil. Ferr. 9, 1988: 141-163.

Billault, A., "Le Dialogue sur l'amour de Plutarque et les Dialogues de Platon sur l'amour", in Aurelio Pérez Jiménez, José García López \& Rosa M. Aguilar (eds.), Plutarco, Platón Y Aristóteles. Actas Del V Congreso Internacional De la I.P.S., Madrid, 1999: 201-214.

Boulogne, J., “Trois Eros? Comment Plutarque réécrit Platon”, in A. Pérez Jiménez et alii (eds.) in Aurelio Pérez Jiménez, José García López \& Rosa M. Aguilar (eds.), Plutarco, Platón Y Aristóteles. Actas Del V Congreso Internacional De la I.P.S., Madrid, 1999: 215-225.

Brenk, F. E., "All for love. The rhetoric of exaggeration in Plutarch's Erotikos", in L. Van der Stockt (ed.), Rhetorical Theory and Praxis in Plutarch. Acta of the IVth International Congress of the International Plutarch Society, Louvain-Namur, 2000: 45-60.

Crawford, M. B., "Amatorius: Plutarch's Platonic departure from the Perigamou literature”, in A. Pérez Jiménez, José García López \& Rosa M. Aguilar (eds.), Plutarco, Platón Y Aristóteles. Actas Del V Congreso Internacional De la I.P.S., Madrid, 1999: 287-298.

Frazier, F., "La 'prouesse de Camma' et la fonction des exempla dans le Dialogue sur l'Amour", in A. Pérez Jiménez \& F. Titchener (eds.), Historical and Biographical Values of Plutarch's Works. Studies Prof. P. A. Stadter, MálagaUtah, 2005: 197-211.

Frazier, F., "Éros, Arès et Aphrodite dans l'Érotikos. Une reconsidération de la réponse à Pemptidès", in J. Ribeiro Ferreira, L. Van der Stockt \& M. Céu Fialho (eds.), Philosophy in Society - Virtues and Values in Plutarch, Leuven-Coimbra, 2008a: 117-136.

Frazier, F., "Introduction", in Plutarque. Éroticos, Dialogue sur l'Amour. Texte établi et traduit par Robert Flacelière. Revu, introduit et annoté par Françoise Frazier, Paris, 2008b.

Gilabert Barberà, P., "El amor en Plutarco: la necesaria corrección platónica de Platón”, in J. M. Nieto Ibáñez \& R. López López (eds.), El Amor en Plutarco. IX Simposio Internacional de la Sociedad Española de Plutarquistas, León, 2007: 123-132.

Jesus, C. A. M., "Semíramis y Émpone. Dos historias de amor y desamor en el Amatorius de Plutarco", in J. M. Candau Morón (et alii, eds.), Plutarco Transmisor, Sevilla, 2011: 69-80. 
Martin, H., "Plutarch, Plato and Eros," CB 60, 1984: 82-88.

Martos Montiel, J. F., "Anotaciones al tema del placer en los Moralia de Plutarco", in J. García López (et alii, eds.), Estudios sobre Plutarco: Paisaje y Naturaleza. Actas del II Simposio Español sobre Plutarco, Madrid, 1990: 67-71.

Martos Montiel,J.F., "Platonismo y Aristotelismo en el concepto plutarqueo del placer”, in A. P. Jiménez et alii (eds.), in Aurelio Pérez Jiménez, José García López \& Rosa M. Aguilar (eds.), Plutarco, Platón Y Aristóteles. Actas Del V Congreso Internacional De la I.P.S., Madrid 1999a: 111-125.

Martos Montiel, J. F., El tema del placer en la obra de Plutarco, Zaragoza, 1999b.

Rist, J. M., "Plutarch's Amatorius: a commentary on Plato's theories of love?", CQ 51, 2002: 557-75.

Teodorsson, S.-T., "Plutarch's views on Love”, Ploutarchos 2, 2004/2005: 105122.

Valverde Sánchez, M., "Tipología del exemplum en el Erótico de Plutarco”, in J. M. Nieto Ibáñez \& R. López López (eds.), El Amor en Plutarco. IX Simposio Internacional de la Sociedad Española de Plutarquistas, León, 2007: 67-82.

Wilamowitz-Moellendorff, U., Kleine Schriften. Herausgegeben von den Akademien zu Berlin und Göttingen. IV, Berlin, 1962. 